\title{
Vail's Story Retold: Applications of John Steinbeck's Realistic Prose to Reconstructing Growth and Change of a Colorado High Mountain Town
}

\author{
Rudi Hartmann \\ University of Colorado Denver, Colorado, USA
}

\begin{abstract}
Vail, a ski area in Colorado established in 1962, has undergone many changes since its inception. How to explain the growth of an ever expanding urban corridor ("Vail Valley") in the Colorado High Country, with considerable implications for the social and built-up environment and the surrounding wilderness? It is argued here that Steinbeck's writings - as laid out, for instance, in Cannery Row - could offer a strategy to reconstruct the events and developments that transformed the Vail ski resort destination over the past decades. Eight chapters lay out major themes of the Vail Story, from "Vail before Vail” to "Vail after Vail." Quotations from Steinbeck's novels and from other writers in the analysis of his works introduce a given theme. The discussion of the beginnings of the ski area and the town, the staging of Vail mega sports events like three world alpine ski championships and the changing directions and policies of the ski corporation result in a narrative closely aligned with the style of Steinbeck's realistic prose.
\end{abstract}

Keywords: Vail, Colorado High Country, John Steinbeck, applications, story telling

\section{Introduction}

Vail, once in a remote non-descript part of the Colorado High Country, is hard to miss when you travel West on I-70. Vail is a narrow urbanized corridor with wide open views of wilderness. Vail is an agglomeration of mansions in gated communities and run-down trailer parks. Vail is for upscale wants and for low budget needs. Vail is deep snow and on the cutting edge of snow grooming. Vail is beautiful and an insult to your eyes. Vail is conspicuously casual, Vail is vain. Vail is reality, Vail is a myth.

Where to start telling Vail's story beyond local tales of legendary achievements and streaks of success, how to grasp the essence of an ever changing complex landscape full of contradictions, how to explain the making of Vail Valley?

John Steinbeck (1902-1968) has contributed to American social history with tomes, like The Grapes of Wrath initially banned in local libraries, but eventually receiving a Pulitzer Prize for being a steadfast and critical voice. Most of his 20 plus novels and non-fiction books are firmly set in Central California (Shillinglaw, 2011). His unique prose depicts places and people in both realistic and imaginary ways. It is argued here that the style and structure of his literature as well as selected Steinbeck themes covered by himself or other authors could serve as a model for examining the sense of place and changing local identities

Rudi Hartmann, Ph.D., Professor, Department of Geography and Environmental Sciences, University of Colorado Denver. 
elsewhere, as here for Vail, Colorado.

In the introductory chapter to Steinbeck's (1945) book Cannery Row, he gives a first poignant characterization of the place marked by contradictory features:

Cannery Row in Monterey in California is a poem, a stink, a grating noise, a quality of light, a tone, a habit, a nostalgia, a dream. Cannery Row is the gathered and scattered, tin and iron and rust and splintered wood, chipped pavement and weedy lots and junk heaps, sardine canneries of corrugated iron, honkytonks, restaurants and whore houses, and little crowded groceries, and laboratories and flophouses.

In the closing words of the paragraph, he reveals how he plans to develop the story line of the book, "The way to write this book (is) to open the page and let the stories crawl in by themselves." This strategy will serve well and can inspire the lay-out of the following eight chapters, from "Vail before Vail" to "Vail after Vail."

\section{Vail Before Vail: Charley Vail, the Person Who Gave Name and Accessibility to the Place}

The western land, nervous under the beginning change. The Western States, nervous as horses before a thunder storm ... The Western States are nervous under the beginning change. Need is the stimulus to concept, concept to action. A half-million people moving over the country; a million more restive, ready to move; ten million more feeling the first nervousness. (Steinbeck, 1939)

Highway 66 is the main migrant road. 66-the long concrete path across the country ... Twisting up into the mountains, crossing the divide and down into the bright and terrible desert ... (the migrants) come into 66 from the tributary side roads, from the wagon tracks and the rutted country roads. 66 is the mother road, the road of flight. (Steinbeck, 1939)

It was Charles D. Vail, long time chief engineer at the Colorado State Highway Department, under whose direction a hard surfaced pass road over a high mountain pass, eventually named in his honor Vail Pass, into the narrow Gore Creek Valley was completed in 1939/40. During his tenure (1930-1945), the mileage of hard surfaced highways in the State of Colorado increased from about 500 in 1930 to 4,400 in 1945. There was a tremendous need to give greater accessibility to the high mountain areas in the West of the State and Charley Vail provided such opportunities for the traveler by car. Among the major projects tackled were the Mount Vernon Road just West of Denver, the road up to Mount Evans above 14,000 feet, the Glenwood Canyon Road, and the Wolf Creek and Monarch passes. It was at the latter pass where he had originally intended to place his name. A new "Vail Pass" near Salida, a republican stronghold, did not fit well with the residents' traditional values. Charley Vail was a well-known and outspoken democrat. Eventually, after enduring protests, the new signs were taken down and it remained Monarch Pass.

Highway 6 over Vail Pass was a new two lane pass road, from the upper Blue River across the pass along the Black Gore Creek, which formed an easier connection to Minturn, Avon, and Glenwood Springs compared to the older and more difficult route via Shrine Pass into Red Cliff. It was in the middle section of the Gore Creek that the Town of Vail would be built in the mid-1960s and the tracks of a much wider interstate 70 were eventually - after debating the viable options - laid in the 1970s. Like the "mother road" from the Dust Bowl ridden portions of the Midwest to the California Coast, I-70 became the main road for long distance truckers and short distance recreational travelers into and across the Southern Rocky Mountains connecting Denver with Salt Lake City and Nevada/Northern California. Not only did Charley Vail give the new ski area and resort town its name but, more importantly, a great location along I-70. 


\title{
Vail Beyond Vail: Gore Creek’s Watershed
}

\begin{abstract}
The Carmel is a lovely little river. It is not very long but in its course it has everything a river should have. It rises in the mountains, and tumbles down a while, runs through shallows, is dammed to make a lake, spills over the dam, crackles among round boulders, wanders lazily under sycamores, spills into pools where trout live, drops in against banks where crayfish live. In the winter it becomes a torrent, a mean little fierce river, and in the summer it is a place for children to wade in and for fishermen to wander in. Frogs blink from its banks and the deep ferns grow beside it. Deer and foxes come to drink from it, secretly in the morning and evening, and now and then a mountain lion crouched flat laps its water. The farms of the rich little valley back up the river and take its water for the orchards and the vegetables. The quail call beside it and the wild doves come whistling in at dusk. Raccoons pace its edges looking for frogs. It is everything a river should be. (Steinbeck, 1945)
\end{abstract}

The Gore Creek is just about 18 miles long. The Gore flows from Gore Lake, a tarn in the upper reaches of the Gore Mountains, underneath the Eagles' Nest peaks at 13,000 feet, South where it is joined by the Black Gore, the Booth Creek, the Pitkin Creek, all near present-day East Vail - and other tributaries including Mill Creek in the Vail Village area. Eventually, the Gore Creek flows into the Eagle River at Dowds Junction near Minturn. The waters of the Gore and Eagle River finally reach the Colorado River at Dotsero which marks the most western end of "Vail Valley."

The upper Gore in the Eagles Nest Wilderness Area is everything a stream in the Colorado High Country should be. Among the perceptible qualities that the observant wanderer can experience along or near the stream are a pristine vegetation cover in the Montane and Alpine eco zones of the higher reaches of the Gore Mountains. After traversing steep ascents with limestone outcroppings from the Minturn formation (some 300 million years old), the hiker is surrounded by aspen groves, stands of fir and Engelmann spruce trees and wide open meadows full of wild flowers during the summer season which comes late to this part of the High Country. While mountain goats and marmots inhabit the sparsely treed, rocky surroundings of the Gore Lake, deer, bears and sporadically a mountain lion call the thickets of the forests home. Mountain squirrels climb, jump, or hop up and down the trunks and branches of growing or dead trees. Jay birds and swallows light shortly on boulders barely sticking out of the running waters of the Gore Creek before they continue their hunt for various insects populating these upper wetlands. The upper stream forms quiet pools after wild and torrent stretches of cascading waters, falls, and cataracts.

While the last four miles of the widening Gore Creek - before it empties into the Eagle River - are still considered a gold medal trout stream, the middle Gore section along the sprawling Vail resort area is marred with problems. In 2011, the Colorado Department of Public Health and Environment put Gore Creek on a state list of impaired waters. The causes for a deteriorated status of the stream, with diminished counts of fish and insects, were multifold. They ranged from the application of herbicides and pesticides for the lawns grown up to the creek edges to an ill-advised community storm water system. The town council decided on implementing the Gore Creek Action Plan, which identifies 27 immediate actions including educating the public that it is not okay to have a stream that does not measure up to standards, no matter how good it still may look (Best, 2016).

Serious water pollution problems in the wider Eagle River Watershed were reported back in the 1980s and 1990s when the Eagle River shimmered at times in an orange hue because of pollutants still coming from the Eagle Mine where once zinc, lead, and gold were extracted. The superfund site upstream from Minturn was eventually cleaned up and the Eagle had fish again. A more complex environmental issue is continued urbanization along an expanding Down Valley, with the streams of the Gore and Eagle River being modified 
and channeled along golf courses, river walks, and paths suitable for the new recreation needs of the Gore Mountains and the Eagle River Watershed.

\section{Vail Becomes Vail: The Finders, Founders and Pioneers of the Vail Ski Area and the Town of Vail}

It has always seemed strange to me ... The things we admire in men, kindness and generosity, openness, honesty, understanding and feeling, are the concomitants of failure in our system. And those traits we detest, sharpness, greed, acquisitiveness, meanness, egotism and self-interest, are the traits of success. And while men admire the quality of the first they love the produce of the second. (Steinbeck, 1945)

Like it or not, the beginnings of Vail are closely tied to a deceptive ploy: the creation of a TransMontaigne Rod and Gun Club along the Gore Creek where not a single shot was fired or if at all for the purpose of disguising the real goal. The false and short-lived organization was set up by Pete Seibert and Earl Eaton, the finders of Vail Mountain who recognized its potential for skiing, jointly with Bob Fowler, a Denver lawyer who came up with the group's name, and John Conway, a folksy real estate man with Western Slope experience. They were eventually joined by George Caulkins, a successful oil man who had moved his company from Oklahoma to Denver and Jack Tweedy, Fowler's law partner. Gradually and consistently, they bought up the lands owned by farmers and ranchers along the Gore Creek Valley in the late 1950s. None of the original owners were told that the deals the TransMontaigne group made with them were intended for the development of the base for a new ski area (Simonton, 1987, p. 62; Hauserman, 2000, pp. 26-28).

Like it or not, these were Indian lands taken away from them. Various Ute Tribes and their ancestors had lived in the Southwest and the Rocky Mountain Regions, a landscape they called the "Shining Mountains," for more than a thousand years. Like the Cheyenne and the Arapahoe who controlled the Eastern Plains of Colorado for about 250 years, they were eventually pushed out by white settlers and miners supported by the United States (U.S.) Government Army after conflicts with and raids by the Indians. While the Cheyenne and Arapahoe had to leave their Colorado hunting grounds for reservations in Oklahoma, Wyoming and Montana, the Utes were pacified with their relocation to two small Indian reservations in the far southwestern desert corner of the state devoid of the animals they once hunted. The founders of Vail were well aware of the environmental knowledge the Utes had accumulated over many generations. In December 1963, at the beginning of Vail's second ski season plagued by poor snow fall conditions, as was the 1962/1963 season, the Utes were invited to perform a snow/rain dance. Sure enough, several days later, a major snow storm hit the area. The Ute blessings would become part of the Vail myth (Simonton, 1987; Hauserman, 2000; Childers, 2012, p. 45).

Like it or not, Pete Seibert and Earl Eaton, the finders/founders of Vail, were not the ones who took advantage of the windfall profits that came with the success of the Vail Ski Area. Pete Seibert, the only person in the group with experience in ski area management, which he had acquired in Aspen and at the Loveland Ski Area in the early/mid-1950s, put his heart into making Vail happen and helping to build the ski area opened in December 1962 and the town founded in 1966 from scratch. He remained at the helm of Vail Associates (VA) for more than a decade to guide the ski area and town through prosperous and shaky times. Earl Eaton was crucial for the initial design of the Vail Ski Area as well as for finding Beaver Creek, the second ski area developed by VA in the 1970s. Eaton was let go many years ago. Pete Seibert lost his influential position at VA when a new owner, Harry Bass Jr., an oilman from Dallas, took over. In the end, we both (the finders/founders 
of Vail) got fired, Earl Eaton once expressed in an interview (Hauserman, 2000, p. 250). Neither Eaton (1922-2008) nor Seibert (1924-2002) died poor. Eaton remained the quiet and humble man he had always been, and he hardly made use of his lifetime ski pass (Martin, 2008). Pete Seibert sold his Vail shares after a gondola accident with four fatalities in 1976, left town and got involved in a ski area venture in Utah, with moderate success and substantial personal financial losses in the investment. Eventually, he returned to Vail as a consultant. Seibert was welcomed back in the community he had helped to create decades ago and he became again part of the fabric of the town and resort company as its iconic founding father. With Vail, he had realized his dream of building a world class ski resort (Seibert, 2000). As president of the American Ski Association and the National Ski Areas Association, he was strongly dedicated to his passion and conviction that skiing should be accessible to everyone (Martin, 2002).

In his recreation of life on old Ocean View Avenue (Cannery Row), Steinbeck chooses a view that excludes and limits women's roles. ... That maybe (is) in keeping with the prevalent adolescent male fantasy that informs the novel's major themes. (Gladstein, 1992, p. 94)

...Women are vaguely perceived as peripheral and ornamental ... This male centered characterization of the lab parties is a choice Steinbeck made. In reality, bright, capable, and independent women were an integral part of the lab group. (Gladstein, 1992, p. 94)

Who were the founders and pioneers of Vail, the early investors in this new ski area venture? They were largely wealthy, driven people, in business or law professions, they were fairly young people, with few exceptions 45 years of age and younger. Seibert and Eaton were 33 and 35 years old respectively when they took their legendary climb of Vail Mountain in March of 1957 and they were men. All the major decisionmakers in the early phases of the ski area and of the town were men (Hauserman, 2000).

The directors and board members of the Vail Corporation, to be named VA, were all men. On the regulatory side, there was Paul Hauk, influential administrator in the White River National Forest Service Office of Glenwood Springs. He met with Pete Seibert and Earl Eaton in 1959, but decided to deny their application for a special use permit. It was Senator Gordon Allott and Congressman Wayne Aspinall who Seibert eventually involved in the process. Their intercession led to a negotiated agreement and a conditional permit with $\$ 2,000,000$ required before ground could be broken. Again, it was George Caulkins and other businessmen from the corporation who pitched in either by arranging financing or soliciting investors.

The outline, design, and construction of the ski area in 1962 besides Seibert and Eaton saw a few other men involved, among them, most prominently, Bob Parker (Best, 2017). Like Seibert, he was a veteran of the $10^{\text {th }}$ Mountain Division, the "soldiers on skis". Eaton served in the Army during WWII and was part of the construction of Camp Hale near Leadville, training center for the 10th Mountain Division. The military background of these men may have helped to overcome the most difficult problems in the logistics of building the base and uphill transportation system including a gondola, a first in Colorado, on the mountain.

Building the Town of Vail was a main project, which saw Fitzhugh Scott, member of the board of directors of VA, in action. As a planner and architect, he was mainly responsible for the design of the Alpine inspired village, including the curved line of Bridge Street at the base of the ski area. Fritz Benedict, another board member and fellow architect from Aspen, and VA Chair Dick Hauserman were part of the three man committee that guided the layout of what would become Vail Village. Other design features derived from Eldon Beck, a San Francisco Bay landscape architect; among others, he introduced the idea of a pedestrian area which made the Village an enjoyable and walkable place. 
Another pioneer in the early development of Vail was Rod Slifer who came as a ski instructor to Vail. While still being a valued member of the Vail Ski School, he started to work as a real estate agent, eventually forming Slifer Smith \& Frampton, which continues to be a powerhouse company in Vail Valley real estate (Colorado Business Hall of Fame, 2013). Not unimportantly for ensuring a constructive business climate in town, Slifer headed the Town Council as Mayor of Vail during two time periods (1977-1985 and 2003-2007).

A leading pioneer in the early days of Vail was Pepi Gramshammer who came as a 31-year-old athlete from Austria to Vail. He bought the prime property on Bridge Street in 1964 to establish the Vail landmark Gasthof Gramshammer. Other men with pioneering achievements in the Vail Community were Tom Steinberg, a physician, who was instrumental in establishing the Vail Clinic and Vail Valley Medical Center, and Don Simonton, a Lutheran minister and co-founder of the Interfaith Chapel as well as initiator and first director of the local Colorado Ski Museum.

Then, there was Terry Minger, one of the savviest persons to ever hit the thin air and rugged mountain environment at 8,150 feet (The Town of Vail's elevation). He arrived in Vail in 1969 and served as the Town Manager from 1970 to 1979, during the years when growth of skiers at the Vail Ski Area skyrocketed, when the sprawling town faced complicated, unforeseen carrying capacity problems and when in 1976 the sky fell with a horrific gondola accident. As Seibert, Minger left eventually town to seek higher grounds by providing leadership and consulting services for the management of other leading Western ski towns, with visions of a green resort and sustainable resort development in high mountain environments (Vail Daily, 2015b).

Skiing was a unifying bond among the men who created Vail. Skiing was a young and adrenalin rushing activity, and a male dominated pastime and sport in the 1960s and 1970s. Among the Vail finders, founders and pioneers were several outstanding ski racers: Pete Seibert, despite a severe WWII injury a Roch Cup Winner in Aspen in 1947, David Gorsuch, who made the U.S. national team in 1958, 1960 and 1962, Austrian skier Pepi Gramshammer, one of the stars of their national ski team in 1959 and the early 1960s, as well as Roger Staub, a Swiss downhiller who won an Olympic gold medal and several world championship titles. He joined Vail for several years until his untimely death in a 1974 accident. Last but not least, there was Bob Parker, Vice President of Marketing at VA and former editor of the Skiing magazine, who made sure that national ski teams and top notch ski racers, such as Jean Claude Killy, repeatedly visited to put Vail on the map.

Women were an integral part of the beginnings of Vail. Of the 202 original investors 36 were women (Hauserman, 2000, pp. 275-277). Though, none of the female investors found themselves in a leading managerial position then. Their role, in a community culture of young couples living and defining an upbeat Vail Spirit and lifestyle in the early days (Hauserman, 2000), was largely peripheral and ornamental.

Three women, wives of earlier mentioned pioneers of Vail, may serve as examples of the substantial contribution women made to the community: Renie Gorsuch, Sheika Gramshammer and June Simonton. Renie Gorsuch, as her husband a member of the national ski racing team during the 1960 Squaw Valley Olympics, was part of the expanding Gorsuch Ltd. venture, with shops for promoting upscale, luxury merchandise first established in Gunnison, then in Vail and eventually in Aspen, Beaver Creek and Keystone (Colorado Business Hall of Fame, 2012). She and Vail society fixture Sheika Gramshammer, a former model and performer in New York and Las Vegas, became leading business women surviving and eventually prospering in the competitive Vail retail and hospitality environment of the 1960s/1970s (Vail Daily, 2017). June Simonton, the local minister's wife who was less connected to the celebratory in-crowds of Vail, became curator of the Colorado 
Ski Museum and the author of a first complete history of Vail, no small feat in a rapidly changing place (Simonton, 1987; Vail Daily, 2013).

Things have changed considerably over the past decades as women attained more managerial positions and became community leaders in various sectors. The first female mayor of Vail was Peggy Osterfoss, before serving her mayoral terms from 1991 to 1995 she was a member of the town council to finalize the Vail Village Masterplan in 1990. The current Mayor Pro Term (2018) is Jenn Bruno, a Vail Village small business owner and councilor since 2013. A woman who broke into the male dominated profession of ski area mountain operations was Elizabeth Howe, since 2013 Senior Director of Mountains Operations for Vail Mountain. She followed the footsteps of two Vail legends who were in charge of the mountain for fifteen years plus each: Sarge Brown and Joe Macy.

Vail ski racing is no longer a male domain. It was Cindy Nelson, a Vailite since 1979, who won Olympic medals and world championship titles for the U.S. in the mid/late 1970s and early 1980s. She was instrumental in the further professionalization and intensification of the skiing sport for women, from designing the course of the Beaver Creek downhill Birds of Prey (with a challenging parallel running course for women) jointly with Swiss downhiller Bernhard Russi to promoting and/or bringing the best talents to Ski Club Vail, such as Lindsey Vonn and Michaela Shiffrin, now the two leading athletes of the U.S. National Ski Team. Right now, Vail women rather than the men in town are representing Vail in the skiing world.

\section{Vail Stages Vail: the World Alpine Ski Championships at Vail \& Beaver Creek}

People like you to be something, preferably what they are. (Steinbeck, 1952)

And now that you don't have to be perfect, you can be good. (Steinbeck, 1952)

Aspen existed a long time before Vail became into being. Aspen, once a rich and fancy silver mining town, was developed as a ski resort with a summer music festival and cultural events after WWII. In 1947, it boasted the longest ski lift in North America. Aspen hosted the 1950 World Alpine Ski Championships, a first in the U.S. As a result, Aspen became an internationally recognized destination by the mid-1950s. Most people who were crucial for founding and establishing Vail either came from or through Aspen. The shadow of Aspen hung over Vail, even in the late 1960s and in the 1970s when more people skied in Vail than in Aspen, when the Vail Ski Area became the largest and most popular ski area in North America (Goeldner, 1978). How did they manage to overcome Aspen's disregard for the Vail upstart?

When Aspen, the internationally most recognized mountain resort, was asked to host the Championships again in 1989, the city declined. During the 1970s, Colorado came under scrutiny by environmental organizations and skiing, or more precisely, ski resort development, was no longer in and aroused suspicion in the anti-growth climate of the state. Thus, Denver's bid to host the 1976 Winter Olympics was rejected in a special election. Beaver Creek, which was supposed to have jointly with Vail the Alpine ski races, became the last ski resort along the I-70 Corridor to be fought over, but eventually it was built (Seibert, 2000; Childers, 2012). As Vail mounted its bid for the 1989 World Alpine Ski Championships in 1983 and succeeded (under the leadership of Pepi Gramshammer and former U.S. President Gerald Ford, then a second home owner there), it also won on a different front. Finally, Vail could showcase its assets, a great mountain for skiing and a hospitable town, to the wider international skiing world. Hosting the 1989 World Alpine Ski Championships enabled Vail to get out of Aspen's shadow of arrogance, perceived by some Vailites as "one of the snottiest 
places on earth" (Vail Daily, 2012). It was at times a bitter but also a constructive rivalry, which would continue for many years to come.

The 1989 World Alpine Ski Championships were blessed (or cursed) by enormous amounts of snowfall during the competition which made an impression abroad. While international visitation (in total visitation) to the Vail \& Beaver Creek ski areas before the Championships in 1989 was in the low range of 3-4\%, afterwards it rose to $13-14 \%$. The 1999 Championships also hosted by Vail and Beaver Creek saw a similar spike after the events.

Vail and Beaver Creek would host the Championships three times (in 1989, 1999, and 2015). Only one other mountain resort, St. Moritz in Switzerland, was given the same honor in the past 50 years. The 1999 World Alpine Ski Championships were in many ways a repeat of the 1989 events. Though, the 1999 Championships had improved race courses and a more luxurious base, as the highly praised "Birds of Prey" downhill course for the men's competition as well as an upscale Village at Beaver Creek was completed.

While the 1989 and 1999 Championships were tightly centered on the race competitions, with focus on the main events and leading athletes of the skiing world, the 2015 World Alpine Ski Championships marked a significant step away or up from this tradition. The press coverage on television (TV) and in the social media was more broadly oriented, towards consumption by a wider audience. It was estimated that over 800 million viewers saw the 2015 events on TV. The FIS Organizing Committee and the Vail organizers tried to reach out to the general public worldwide and in the U.S., making, for instance, the case for the continued appeal of the skiing sport, in particular, to America's youth. The 2015 Championships were the first complete event and the celebration of the alpine skiing sport at Vail \& Beaver Creek in February 2015 presented itself as a "Mini-Olympic" (Hartmann, 2017, pp. 46-47).

Population in Vail Valley/Eagle County has more than doubled from 22,000 in 1990 to 52,000 in 2010. While the growth cannot be attributed to the Championships in a narrow sense or to an increased popularity of the skiing sport and the availability of more recreational opportunities in general, it provides a first answer to one of the draws for living and working in Vail Valley. Over the past decades, Vail Valley has become an all season tourist destination. Vail was able, with the Championships and many more professional and cultural events initiated for the summer and shoulder seasons, to define itself in a more distinct way, thus creating a magical touch while staging Vail at times.

\section{Vail Against Vail: Controversies Over Expansions of Skiable Terrain on the Mountain}

Mac: A strike that is settled too quickly will not teach the men how to organize, how to work together. A tough strike is good. We want the men to find out how strong they are when they work together. (Steinbeck, 1936)

Mr. Anderson: You know what your problem is? You never won anything. You never planted trees, watched them grow, touched them with your own hands. You bastards never owned anything. You never put your hands in your own dirt. Mac: With respect, we never had a chance to own nothing. (Steinbeck, 1936)

“This (expansion) has nothing to do with skiing!" Berman shouted when he got his chance at the microphone. ... He reminded the crowd that the report had recently purchased an option to develop a huge tract of private land just a mile from Cat III. "This is all about real estate", he shouted as the crowd erupted in applause. (Markels, 1999)

“...Vail sweeps up the ashes of eco-terrorism and opens its newest powder paradise: ... Blue Sky Basin (formerly known as Category III expansion) has been at the center of a prolonged environmental battle that climaxed in a fiery arson attack by the Earth Liberation Front that destroyed Vail's Two Elk Lodge in October 1998". (Markels, 2000) 
During the 1980s and 1990s, Vail and the company that owned and managed the Vail and Beaver Creek ski areas went through turbulent times. Harry Bass' take-over of VA in 1978-1979 and his ill-fated ownership ended in 1984. Economic problems, most prominently the recession 1980-1982 and an extended period of high interest rates, were accompanied by the snow parched 1980-1981 ski season as well as initial problems at the new Beaver Creek ski area. When George Gillet, an owner of media companies and a large meat packing house, purchased VA in 1984-1985, new enthusiasm in the Vail business community emerged. Gillett introduced customer oriented policies and he was also very supportive of the 1989 Championships as well as hosting them again. Yet, Gillett Holdings, the parental company of VA, had to go through bankruptcy starting in 1991. Apollo Management, a Wall Street Company and majority owner of VA by the mid-1990s, decided to go public to form Vail Resorts Inc. in 1997. Associated with the organizational and financial turbulences that hit the company in the 1990s Vail Resorts opted for continued rapid growth, for the ski areas they managed as well as for the land they controlled on the valley floor. The growth policies of the corporation, though, would run against the public sentiment in the mid and late 1990s. While an expansion of the Vail Ski Area into China Bowl and Siberia Bowl was tolerated, thus making Vail the largest ski area in the U.S. again, the next piece of the puzzle on Vail Mountain, the Category III expansion, was in doubt.

As in the early \& mid 1970s, a coalition of environmental groups in and outside Vail Valley opposing further designation of federal lands for ski area development evolved in the 1990s. The issue was no longer of whether more lands should be carved out for the improvement of skiing but rather of should this be done for the sake of the profits of the large companies and corporations increasingly in charge of the process (Best, 1998; Clifford, 2002). The case in question was the Category III expansion on Vail Mountain pushed by VA/Vail Resorts and growth oriented factions in the Valley. For the environmentalists spearheaded by the Colorado Environmental Coalition, it came down to this: the alternative of an (unnecessary) Super Vail expansion or the protection of the habitat of the threatened lynx and other wildlife populations (CYBERWEST, 1997). When the Forest Service agreed to give their OK to the expansion, which was part of the 1986 Master Plan, and to allow beginning of the construction, the confrontation culminated in an arson attack in October 1998 when seven structures on the mountain including the large Two Elks Lodge went up in flames. Members of the Earth Liberation Front claimed the responsibility for the act inspired by their goal to save the lynx.

As in Steinbeck's (1936) In Dubious Battle, when a strike among workers in apple orchards faltered after a barn with the collected harvest crop burnt down, the violent action on the mountain backfired. As In Dubious Battle, it was a far reaching political agenda that strikers then had against the owners' practices of wage manipulation that the 1998 Vail expansion protesters for the sake of the preservation of the environment and of animal rights pursued. The act of the arsonists hailed by few as 'eco warriors' was largely decried in the public as a form of eco-terrorism and ultimately dismissed by all the groups involved in the open dialogue and debate over the expansion. At last, the fires on the mountain re-united the community behind Vail Resorts' business agenda of a bigger Vail as a better Vail (Best, 2012; Stoner, 2005).

What happened to the Category III expansion, what happened to the lynx? The Category III tracts of land were fully developed in 1999 and opened as "Blue Sky Basin" on January 6, 2000. In December, 2000, another 125 acres were added to the 520 acres of varied skiable terrain. Though not as large as the China Bowl and Siberia Bowl extensions, it has been a great asset to the Vail Ski Area as it opened the back bowl areas to intermediate skiers. Another quality of the Blue Sky Basin was its North facing slopes enabling excellent skiing conditions even late in the season. From 1999 to 2006, 218 Canadian Lynx were reintroduced into the large 
Weminuche Wilderness Area in Southwest Colorado. It was a program partially subsidized by Vail Resorts. After 15 years, the Lynx reintroduction program has been widely considered a success with a sufficient number of animals surviving and reproducing litter (at least 141 born in Colorado) (Devineau et al., 2010; Denver Post 2010). There were even a few lynx sightings in the Vail area.

\section{Vail Moves Down Valley: Migration to the End of the Valley}

The cars of the migrant people crawled out of the side roads onto the great cross-country highway, and they took the migrant to the West. And because they were lonely, and perplexed, because they all came from a place of sadness and worry and defeat, and because they were all going to a new mysterious place, they huddled together; they talked together, they shared their lives, their food, and the things they hoped for in the new country. (Steinbeck, 1939)

The Cannery Culture: Canneries and packing houses in California have historically been lucrative enterprises, yet their workers, particularly women, reaped few benefits. They labored long hours for low pay under hazardous, unsanitary conditions. Moreover, sexual and ethnic divisions of labor have served to separate workers from each other ... A myriad of factors, including ethnic discrimination, relegated Mexican women to the lowest positions on the production line. (Ruiz, 1987, p. 21)

As Vail's mountain became bigger and better, and the town itself morphed into a full-fledged four season destination with tourists arriving year-round, real estate values have increased tremendously. Since the late 1990s prices have jumped by double digit figures, almost every year. As a result, housing in or near Vail Village, Lion's Head and Beaver Creek has become inaccessible for a large part of the local working populations. Due to the dire situation, many Vailites moved downstream to Down Valley locations where homes, apartments, and mobile homes for rent or sale were still available at more reasonable rates. Despite initiatives and programs supported by VA/Vail Resorts, The Town of Vail and agencies within Eagle County the shortage in affordable housing has persisted.

Clearly, there is a huge and widening affordability gap for workers living in Vail Valley communities which prevent them from buying a home (Vail Daily, 2015c). Moreover, rents are at a sky high level, compared to those in nearby rural areas/counties. Thus, it is not uncommon for young incoming workers to share rental space and to work two or three jobs to make ends meet. Hispanic single moms with their children crammed into trailer parks in Edwards barely get by, only by renting out scarce surplus space of their trailer (Colorado Public Radio News, 2015). Other low wage earners, such as maids working the shifts in the resort hotels, have chosen to live far away from Vail, as far as Leadville, Lake County, to make a daily forty mile commute (via shuttle bus) back and forth across mountain passes.

As the core resort areas saw an increasing influx of tourists, of second home and time share owners, Vail became an empty shell, a "hollowed-out community" in the words of Myles Rademan (Lichtenstein, 2004; Rademan, 2003). The once thriving social life among Vail's pioneers and the locals in town thinned out. New communities developed in Down Valley locations. Places like the Town of Avon, Edwards and the Town of Eagle now offer a multitude of cultural, social, and educational opportunities for locals. As a result, the Down Valley has a fairly rich and varied, at times vibrant community life. What once used to be Vail has moved in droves down the valley. And thousands of newcomers to the valley, many of them arriving from Mexico and Latin American countries, have set up residence there as well.

Not surprisingly, the population volumes of the Down Valley communities, with sizable Hispanic or Latino groups, have surpassed Vail, according to 2016-2017 census figures, with its current population of 5,305 people (90\% white Caucasian and 7\% Hispanic or Latino). Avon, a service center at the base of the upscale 
Beaver Creek Village \& Ski Area, has a population of 6,447 people (with $49 \%$ being Hispanic or Latino). Farther Down Valley are Edwards with 10,266 residents (31\%) Hispanic or Latino, the Town of Eagle with 6,508 residents/22\% Hispanic or Latino and Gypsum 6,477 (44\%) Hispanic or Latino. Vail Valley, stretching from Vail Pass/East Vail to Gypsum/Dotsero on the western end, has become a heavily urbanized complex corridor of close to 50 miles.

Vail and the other core resort areas could not function without the services provided by the Down Valley. It is there where the unsightly bulky infrastructure is found, from gravel pits for construction materials, car repair shops with waste tires to simple business structures tucked into commercial strips. It is there where passengers land at the Eagle County Regional Airport before they are swiftly shuttled to their fancy hotels or time shares in gated communities in Beaver Creek and up to Cordillera. It is there where maturing or dilapidated trailer parks and monotonous rows of red roofed employee housing populate the fringes of the Down Valley communities.

While the core resort areas such as Vail Village and Lion's Head have seen waves of restructuring, redevelopment and many forms of beautification of the older sections hailed by some as a 'renaissance' of Vail (Stoner, 2007, Martin, 2008, Filgo, 2008), the end of the Valley in Gypsum/Dotsero holds another side of the present and future of Vail. It is a mix of functional and ramshackle housing, and new recreation sites, such as a public golf course, guest ranches, and two zip line venues each about ten miles away as well as industrial plants, like the Colorado Mountain News Media headquarters and shop, a media group owned by Nevada based Swift Communications. Swift, a large publishing company that has specialized in small town newspapers of the West, has most often gained a controlling interest in local advertising. It is in Gypsum, at the end of the Valley, where the Vail Daily, the Aspen Times, the Summit Daily, and half a dozen other newspapers serving the resort town communities on the Western Slope are printed. Here, the daily or weekly narrative for the resort communities of the Colorado High Country including Vail, with a circulation of 13,000 , is finalized and distributed as hard copies at stands and in digital versions.

\section{Vail Comes of Age: Hopes for a Sustainable Future?}

Power does not corrupt. Fear corrupts ... perhaps the fear of a loss in power. (Steinbeck, 1957)

Katz has unquestionably overachieved. It is easy now to forget Katz's steering of the ship through the Great Recession. ... Katz brought with him Wall Street savvy, an ability to manage up to his owners and shareholders, and just enough empathy and intuitive understanding of the resorts' communities that he could drive change without destructive resistance. (Diamond, 2016, p. 160)

It all started with skiing, with a small, confined Vail Ski Area/Vail Village in the beginnings, which gave name to the place and the valley. As the resort grew up, matured, expanded and excelled, it received the honor of hosting three World Alpine Ski Championship mega events. The high powered competitions brought the best athletes in the skiing world to town and the Valley. Each time, the hosting organization and the residents were faced with updating their skills, amenities and infrastructure to stage the events in state-of-the-art-fashion. The championships and skiing, recreation and tourism in a wider sense have changed Vail Valley not only in area size and population volume, but also qualitatively. It made Vail and Beaver Creek resort destinations with high standards in professional services.

Vail has come of age (Town of Vail, 2012). A new pride has taken root in town, expressed, for instance, in the popular slogan-There is no place like Vail. Celebratory words that reinforce what has been achieved and 
come in broad consensus with business and civic leaders, frequently from the local press. "In the past 50 years, Vail Village and Vail Mountain have undergone dramatic growth, serving to take Vail to the international prominence and elite status it now enjoys" (Filgo, 2008). Needless to say the local Colorado Ski Museum contributed to the evolving narrative, with a skillfully arranged, ski and snowboarding focused, special exhibit for the anniversary events: Vail Dream Realized in 2012 and Vail's DNA in 2018. While myths of the past flare up, come and go, the resort chamber and the ski corporation are mostly concerned with the daily and future challenges awaiting them in a very competitive industry environment.

In 2006, the Vail Resorts corporate headquarters were moved out of Vail Valley, to Broomfield on the Front Range where the new Leeds certified high rise building overlooks a tech heavy section of U.S. Highway 36 between Denver and Boulder. More importantly, leadership and policy changes came with the move: Rob Katz, a former executive officer of Apollo Management, took over and introduced the new Epic brand for Vail (as in Epic Pass, Epic Promise, and Epic Adventure) as well as a sustainable development strategy for Vail Resorts' global ambitions. Is a sustainable future for Vail still possible, in an environment that had been largely sacrificed for growth and glamour in past decades? The chief executive officer (CEO) Rob Katz of Vail Resorts thinks so, "The environment is our business and our passion" (Katz, 2017, as cited in Blevins, 2017).

The new environmental agenda, now actively including Vail Resorts' employees in the 12 ski resorts they manage in the U.S. and Canada, was widely and effectively communicated by the corporation. Vail Resorts' latest initiatives comprise the "Epic Promise for a Zero Footprint" with the goal of eliminating the environmental impact of its operations by 2030 including delivering zero waste to landfills and to offset its overall impact to forests and habitats (praised by partner The Nature Conservancy). The resort company promises to use only renewable energy by 2030 . Vail Resorts also plans to join the RE 100, a group of global companies committed to using 100 percent renewable energy. Vail Resorts would be the first tourism group to join the RE 100 (Blevins, 2017).

Questions continue to emerge of whether Vail Resorts' business approach in the sustainability field will truly bring change in Vail and the other ski resorts they own. It remains to be seen whether Robert Katz's 'smart business' sustainability strategy will materialize. Aspen Ski Company's Vice President of Sustainability, Auden Schendler, a long-term critic of marketing driven policies in the sustainability field, has toned down his skepticism and acknowledged Vail Resorts' new voice and political power to drive change on climate issues (Schendler, 2017, as cited in Blevins, 2017). While it is not quite clear whether Katz's goals are aimed at the sustainability of the environment (in the Colorado High Country) or at the sustainability of the business operations (of Vail Resorts), his lofty agenda has caught the attention of the industry and the ski towns.

\section{Vail After Vail: Climate Change Comes to the Colorado High Country}

The publication of Steinbeck's “Cannery Row” in 1945 coincided with the zenith of Monterey's sardine fishing and canning era, as wartime production enabled its proclamation as "Sardine Capital of the World!" The echoes of this proud boast had hardly faded when the Monterey sardine industry and the community it supported, were visited by an irony and agony of catastrophic proportions. The 1945-1946 seasons were nearly half of the volume of the previous year's catch. A stunned industry held its breath and awaited the 1946-47 season; it was to be the worst since 1922 ! And the 1947-48 season was to be, unbelievably, even worse. (Hemp, 2014, p. 108)

Cannery Row's unlearned ecological-economic lessons still haunts the world's oceans and collapsing fisheries today. (Hemp, 2014, p. 9) 
Both prescient and prophetic, Sea of Cortez (Steinbeck \& Ricketts, 1941) is especially notable for its early recognition that the ocean's resources are finite and cannot withstand for long the pressures of wasteful and destructive fishing practices. (C. E. Gladstein \& M. R. Gladstein, 1997, p. 161)

Will climate change lead locally and regionally to a decline of winter sports activities? Global warming has already visibly affected glaciers, ice shields, and snow cover in the Arctic and in high mountainous areas. Predictions are that this will continue at an even more rapid pace. The seasonal snow pack in winter sports regions like the Alps and the Northeast of the U.S. and of Canada has shown marked - and at times shocking losses (Burakowski \& Magnusson, 2012; Dawson, Scott, \& Havitz, 2013; Rutty et al., 2015). Photographs of grassy ski slopes devoid of any snow at the beginning or even in the middle of the winter season have alarmed the skiing public and the managers of the ski areas. Could such potentially disastrous trends affect ski areas in the Rocky Mountains as well?

In 2007, a team of climatologists and snow experts conducted research in the Rocky Mountain Region (Lazar \& Williams, 2008). According to the Colorado study, "Rocky Mountain ski areas face dramatic changes this century as the climate warms, including best-case scenarios of shortened ski seasons and higher snowlines and worst-case scenarios of bare base and winter rains" (University of Colorado CU Boulder Today, 2008). Fortunately, Colorado's ski areas, located in a continental climate region at a high elevation, may fair better than other destinations near coastal areas with wetter conditions. Rocky Mountain ski areas appear to be less prone to change and are, in the short run, more resilient. Though, results from research in Aspen and Park City indicate that changes are coming mid and long term in the form of a diminished length of the ski season. Snow melt and the run off in spring already occur weeks earlier compared to the 1970s/1980s, and the outlook is bleak. Temperatures are expected to rise by four degrees Fahrenheit by 2030. The results also showed that researchers expect the density of the snow to increase, from the desirable powder snow conditions, highly praised for ski areas in the Rocky Mountain Region, to denser, more compacted snow consistencies (Green, 2015; Hendee, 2016).

Climate change as it may play out in the Southern Rockies will come down to this: Can mountain managers and their teams maximize their operations to maintain, with increased and more effective artificial snow making, a normal length ski season of close to 140 days despite the apparent changing natural conditions? Or will it become simply too costly and too labor intensive to implement an array of new management practices with more water resources needed? Can the decision makers at ski resorts 'weatherproof' (CBS News, 2016) the season by offering alternative activities, for instance at indoor adventure centers, when outdoor winter sports activities are no longer possible or a desirable option?

The need to address these questions may come sooner than later, after the record low snow fall during the early 2017/2018 season including the holidays. Can the Vail ski corporation absorb the losses of another dismal ski season without making painful cuts and other necessary adjustments? Can Vail Resorts, a public company owned by shareholders with expectations of consistent short term profitability, cope with an extended period of drought years? Unlike the crisis ski seasons of 1976/1977 and 1980/1981, when skiing was an in sport and not that expensive (as it is in today's market), Vail easily bounced back. Nowadays, the skiers in and outside Colorado have choices by frequenting less costly ski areas nearby. As Vail receives on an average basis less snow compared to ski areas farther north, such as Steamboat (with predictably better powder skiing conditions) or ski areas higher up, such as Arapahoe Basin and Loveland (possibly the future of spring skiing in Colorado), Vail Resorts' Epic Ski Pass, soon to reach the \$1,000 mark, might see fewer loyal customers in the years to come. 
On a more general note, it is the challenge of climate change and the implementation of effective policies of limiting a further increase in greenhouse gases that will determine the question of whether Vail can prosper long-term as a place for skiing. Will Vail Resorts become an animal too big to survive in an era of global warming, a "T Rex" of the ski resort industry, or even with the calculated risk of reducing services to the public (while inviting more privatization on the mountain) "sardines", like in Steinbeck's Cannery Row - no longer plentiful in an ocean of overfished entertainment possibilities?

\section{Conclusions}

To finish is sadness to a writer, a little death. He puts the last word down and it is done. But it is not really done. The story goes on and leaves the writer behind, for no story is ever done. (Steinbeck, 1975)

Vail's story is far from being done. New chapters may crawl into the pages of the story book. Vail is not done yet. It continues to evolve, in and with an ever changing environment. Slow and dramatic changes might hit the town and valley. Great things might come to fruition, as some Vailites hope. Severe downturns could occur, as others fear.

New generations of Vailites will build a new reality and spin their own myths. New breeds of historians will present a different kind of retrospective, with themes not yet covered coming to the forefront. Their Vail Story might form a new and valid version to be enjoyed by many.

New audiences, on and beyond the internet, might seek and find new meanings to words written in yesteryear. Hopefully, new generations of readers will be willing to remember a four letter word that sounds like \'vā $\backslash \backslash$ (phonetics for Vail). Pete Seibert, once grappling with a good, pronounceable name for the place and mountain he and Earl Eaton had found, thought it was just fine. Charley Vail might have agreed with them, had he known that he ultimately became the starting point for an evolving Vail Story.

\section{References}

Best, A. (1998). Vail and the road to a recreational empire. High Country News, 30(23), 1 \& 10-15.

Best, A. (2012). Vail expansion was about bigger = better. Mountain Town News, September 19, 2012.

Best, A. (2016). Vail's Gore Creek looks pristine, but bug counters tell a different story. Mountain Town News, April 27, 2016.

Best, A. (2017). Bob Parker, a crucial figure among founders of Vail, died June 29. Vail Daily, July 6, 2017.

Blevins, J. (2017). World's largest operator vows to be clean by 2030. Denver Post, July 26, 2017, pp. 10/12.

Burakowski, E., \& Magnusson, M. (2012). Climate Impacts on the Winter Tourism Economy in the United States. New York, N.Y.: Natural Resources Defense Council (NRDC).

Childers, M. (2012). Colorado powder keg: Ski resorts and the environmental movement. Lawrence, Kansas: University Press of Colorado.

Clifford, H. (2002). Downhill slide-why the corporate ski industry is bad for skiing, ski towns and the environment. San Francisco: Sierra Club Books.

Colorado Business Hall of Fame. (2012). David and Renie Gorsuch: 2012 Colorado Business Hall of Fame. Denver: Author.

Colorado Business Hall of Fame. (2013). Beth \& Rod Slifer: 2013 Colorado Business Hall of Fame Laureate. Denver: Author.

Colorado Public Radio News. (2015). In Vail Valley, Low-Wage Workers Sacrifice Privacy to Make Rent. Retrieved from $\mathrm{http}: / / \mathrm{cpr} .0 \mathrm{rg} / \mathrm{n}$ ews/story/vail-valley-low-wage-workers-sacrifice-privacy-to-make-rent/htlm

Columbia Broadcasting System (CBS) News. (2016). Hitting the plastic slopes: Climate change pushes ski resorts to weatherproof. August 13, 2016.

CYBERWEST (1997). Environmentalists oppose "Super Vail" expansion. Retrieved from http://cyberwest.com/12green1/html

Dawson, J., Scott, D., \& Havitz, M. (2013). Skier demand and behavioral adaptation to climate change in the US Northeast. Leisure, 37(2), 127-143. 
Denver Post. (2010). Lynx reintroduction ruled a success in Colorado. Retrieved September 17, 2010, from http://www.denverpost.com/2010/09/17/lynx-reintroduction-ruled-a-success-in-Colorado

Devineau, O., Shenk, T. White, G., Doherty, P., Lukacs, P., \& Kahn, R. (2010). Evaluating the Canada lynx programme in Colorado: Patterns in mortality. Journal of Applied Ecology, 47(3), 524-531.

Diamond, C. (2016). Ski INC. Steamboat Springs: Ski Diamond Publishing.

Filgo, K. (2008). Vail Village: Old and new, there's no place like Vail. Vail Daily, December 20, 2008.

Gladstein, C. E., \& Gladstein, M. R. (1997). Revisiting the sea of Cortez with a green perspective. In S. Beegel, S. Shillinglaw, \& W. N. Tiffney (Eds.), Steinbeck and the environment (pp. 161-175). USA: University of Alabama Press.

Gladstein, M. R. (1992). Cannery row: A male world and the female reader. Steinbeck Quarterly, 25(3-4), 87-97.

Goeldner, C. (1978). The Vail Skier: 1977-1978 Season. Boulder, Colorado: Business Research Division, University of Colorado Boulder.

Green, D. (2015). The threat of global warming on the Colorado ski season. University of Colorado Boulder: CU Independent.

Hartmann, R. (2017). The world Alpine Ski championships 1989, 1999 and 2015 in Vail, Colorado: Impacts, Issues and the Quest for Sustainable Resort Development. International Journal of Research in Tourism and Hospitality, 3(3), 43-53.

Hauserman, D. (2000). The inventors of Vail. Edwards, CO: Golden Peak Publishing Company.

Hemp, M. K. (2014). Cannery Row: The history of John Steinbeck's Old Ocean View Avenue. Carmel, CA: The History Company.

Hendee, C. (2016). Colorado ski areas may get lucky on climate change. Denver Business Journal, October 18, 2016.

Lazar, B., \& Williams, M. (2008). Climate change in western ski areas: Potential changes in the timing of wet avalanches and snow quality for the Aspen ski area in the years 2030 and 2100. Cold Regions Science and Technology, 51, 219-228.

Lichtenstein, G. (2004). Part-Time Paradise: Mountain towns echo with construction activity, but the resulting homes lie silent much of the year. High Country News, October 25, 2004.

Markels, A. (1999). Backfire. Mother Jones, March/April 1999 Issue.

Markels, A. (2000). Blue sky's noisy dawn. Retrieved from http://www.outsideonline.com?1888811/blue-sky-noisy-dawn/html

Martin, D. (2002). Pete Seibert, Soldier Skier who built Vail, is dead at 77. New York Times, July 28, 2002.

Martin, D. (2008). Earl Eaton, a founder of the Vail Skiing Resort, is dead at 85. New York Times, May 31, 2008.

Martin, R. (2008). In Renaissance, Vail confronts its future. Retrieved from https://newwest.net/topic/article/vails_renaissance/C35/L35/html

Rademan, M. (2003). Change comes to the mountains: Tourist towns face an uncertain future. Planning, 69(1), 16-19.

Ruiz, V. L. (1987). Cannery women, cannery lives: Mexican Women, unionization, and the California food processing industry, 1930-1950. Albuquerque: University of New Mexico.

Rutty, M., Scott, D., Johnson, P., Jover, E., Pons, M., \& Steiger, R. (2015). The geography of skier adaptation to adverse conditions in the Ontario ski market. The Canadian Geographer, 59(4), 391-403.

Seibert, P. (2000). Vail: Triumph of a dream. Boulder, CO: Mountain Sports Press.

Shillinglaw, S. (2011). A journey into Steinbeck's California. Berkeley, CA: Roaring Forties Press.

Simonton, J. (1987). Vail: Story of a Colorado Mountain Valley. Denver: Bear Tree, Inc.

Steinbeck, J. (1936). In dubious battle. New York, N.Y.: Penguin books republished in 1979.

Steinbeck, J. (1939). The grapes of wrath. New York, N.Y.: Penguin Books republished in 1981.

Steinbeck, J. (1945). Cannery row. New York, N.Y.: Penguin Books republished in 1987.

Steinbeck, J. (1952). East of Eden. New York, N.Y.: Penguin Books republished in 1987.

Steinbeck, J. (1957). The short reign of Pippin IV. New York, N.Y.: Penguin Books republished in 1986.

Steinbeck, J. (1975). The art of fiction, The Paris Review, 63(Fall).

Steinbeck, J., \& Edward F. R., Jr. (1941). Sea of Cortez: A leisurely journal of travel and research. Mt. Vernon, NY: Paul P Appel.

Stoner, E. (2005). Arson sparked local support for expansion. Vail Daily, December 20, 2005.

Stoner, E. (2007). Vail renaissance or the dark ages? Vail Daily, September 11, 2007.

Town of Vail. (2012). Vail's first 50: A retrospective 1962-2012. Vail: Author.

University of Colorado Boulder CU Boulder Today. (2008). Warming Climate Signals Big Changes for Ski Areas, Says New Colorado Study. Retrieved December 15, 2008, from https://www.colorado.edu/today/2008/12/15/warming-climate-signalsbig-changes-for-ski-areas-says-new-colorado-study/htlm

Vail Daily. (2012). Vail 50th anniversary: How Aspen begat Vail. December 21, 2012. 
Vail Daily. (2013). Vail pioneer June Simonton: Delightfully unique. February 27, 2013.

Vail Daily. (2015a). Local ski museum founder Don Simonton passes away. March 22, 2015.

Vail Daily. (2015b). Terry Minger receives second annual Torch Award. November 12, 2015.

Vail Daily. (2015c). Vail Valley workers losing ground in home buying. September 10, 2015.

Vail Daily. (2017). Sheika Gramshammer honored for Lifetime Achievement by the Vail Centre. February 8, 2017. 